\title{
Antineutrophil Cytoplasmic Antibody-Positive Glomerulonephritis Associated with Long-Term Propylthiouracil Treatment in Children
}

\section{Çocukluk Çağında Uzun Dönem Propiltiourasil Kullanımına Bağlı Gelișen Antinötrofil Sitoplazmik Antikor ilișkili Glomerulonefrit}

\author{
Engin Köse1, Gökçe Yegül Gülnar1, Seda Şirin Köse1, Zehra Serap Arıcı1, Malik Ergin5, \\ Gönül Çatlı4, Ahmet Anık4, Önder Yavaşcan2, Bumin Nuri Dündar3, Nejat Aksu2 \\ ${ }^{1}$ Tepecik Training and Research Hospital, Clinic of Pediatrics, Izmir, Turkey \\ 2 Tepecik Training and Research Hospital, Clinic of Pediatric Nephrology, Izmir, Turkey \\ ${ }^{3}$ Tepecik Training and Research Hospital, Clinic of Pediatric Endocrinology, Izmir, Turkey \\ ${ }^{4}$ Dokuz Eylül University Faculty of Medicine, Department of Pediatric Endocrinology, Izmir, Turkey \\ ${ }^{5}$ Dr. Behçet Uz Child Disease and Pediatric Surgery Training and Research Hospital, Clinic of Pathology, Izmir, Turkey
}

\begin{abstract}
A seventeen-year-old girl was referred to the hospital with complaints of nausea, vomiting, inappetence, malaise and sweating. She was diagnosed with Graves's disease at another hospital 11 years prior to her current presentation, and she was on treatment with propylthiouracil (PTU). According to the results of laboratory investigations (urea: $45 \mathrm{mg} / \mathrm{dL}$, creatinine: $1.3 \mathrm{mg} / \mathrm{dL}$, GFR: $41 \mathrm{~mL} / \mathrm{min} / 1.73 \mathrm{~m}^{2}$ ) she was diagnosed with stage 3 chronic renal failure. Renal biopsy was also consistent with chronic glomerulonephritis. Serologic evaluation revealed positive cytoplasmic antineutrophil cytoplasmic antibodies (C-ANCA). ANCA positive pauciimmune glomerulonephritis associated with PTU treatment was considered. Radioactive ablation treatment was performed because of persistent hyperthyroidism. PTU treatment was discontinued and enalapril, propranolol and steroid treatments were initiated. After one month, her proteinuria, C-ANCA and serum creatinine levels were regressed and renal function wasimproved. Currently, she is followed with tapering dose of prednisone as well as enalapril, and propranolol therapy. This case highlights that ANCApositive glomerulonephritis should be considered as a potential side-effect of PTU. Patients treated with PTU should be carefully monitored for ANCA titers and the variable manifestations of ANCA-associated glomerulunephritis regardless of the period of administration. The Journal of Pediatric Research 2014;1(4):222-5
\end{abstract}

Key Words: Propylthiouracil, antineutrophil cytoplasmic antibody, glomerulonephritis, children

\section{ÖZET}

On yedi yaşında kız hasta, servisimize bir haftadır devam eden bulantı, kusma, iştahsızlık, halsizlik ve terleme şikayetleriyle başvurdu. On bir yıl önce Graves hastalığı tanısılla takip edildiği ve 0 zamandan bu yana propiltiourasil (PTU) tedavisi aldığı belirtildi. Laboratuvar tetkikleri ile evre 3 kronik böbrek hastalı̆ıı (üre: 45 mg/dL kreatinin: 1,3 mg/dL, GFR: 41 mL/dk/1,73 m²) tanısı konuldu. Böbrek biyopsisi kronik glomerulonefrit ile uyumlu saptandı. Serolojik incelemede sitoplazmik antinötrofil sitoplazmik antikor (C-ANCA) pozitif olarak saptandı. PTU kullanımına bağlı ANCA pozitif glomerulonefrit tanısı düşünüldü. Persistan hipertiroidizm sebebiyle radyoaktif ablasyon tedavisi yapıldı. PTU tedavisi kesilip enalapril, propranolol ve steroid tedavisi verildi. Bir ay sonra olgunun proteinürisi, C-ANCA ve serum kreatinin değerlerinde gerileme saptandı. The Journal of Pediatric Research 2014;1(4):222-5

Anahtar Kelimeler: Propiltiourasil, antinötrofil sitoplazmik antikor, glomerulonefrit, çocuk 


\section{Introduction}

Propylthiouracil (PTU) is a thioureylene derivative commonly used to treat hyperthyroidism. Fever, arthralgia, rash and agranulocytosis are the most common side effects, however, more serious complications such as hepatitis, vasculitis and a lupus-like syndrome may occur (1-3). Furthermore, antineutrophil cytoplasmic antibody (ANCA)positive glomerulonephritis (GN) with, or without, systemic vasculitis $(4,5)$, lupus nephritis (6), Wegener's granulomatosis (7), acute and chronic interstitial nephritis have been well documented in association with PTU in both children and adults $(8,9)$.

We report a case of a 17-year-old girl treated with PTU for Graves' disease who developed chronic renal failure due to long-term and uncontrolled PTU treatment associated ANCApositive glomerulonephritis.

\section{Case Report}

A Seventeen-year-old female was referred to the hospital with complaints of nausea, vomiting, anorexia, malaise and sweating.

She was diagnosed with Graves' disease at another hospital 11 years prior to her current presentation. Treatment with PTU was initiated at the time of diagnosis, however, there was no information on thyroid function tests, PTU medication dose and duration of treatment because of the absence of regular medical observation.

On admission the patient was conscious, her skin was wet. Tremor was detected on hands. Physical examination revealed a weight of $47.5 \mathrm{~kg}$ (3-10 th percentile)and her height was $149 \mathrm{~cm}\left(<3^{\text {th }}\right.$ percentile). Respiratory rate, heart rate and blood pressure were 24 per minute, 100 per minute and $125 / 83 \mathrm{~mm} \mathrm{Hg}$ respectively (>95th percentile for age, sex and height). The thyroid gland was evaluated as stage 2 thyromegaly. Other systems were normal. Skin eruption, arthritis, scleritis and other systemic vasculitis findings did not exist.

Laboratory studies showed white blood cell count 6.630/ $\mathrm{mm}^{3}$, red blood cell count $3.980 .000 / \mathrm{mm}^{3}$, hemoglobin 10.2 $\mathrm{g} / \mathrm{dl}$, platelet count $304.000 / \mathrm{mm}^{3}$, urea $56 \mathrm{mg} / \mathrm{dl}$, creatinine
$1.5 \mathrm{mg} / \mathrm{dl}$, sodium $135 \mathrm{mEq} / \mathrm{L}$, potassium $4.6 \mathrm{mEq} / \mathrm{L}$, calcium $9.1 \mathrm{mg} / \mathrm{dl}$, phosphorus $4.1 \mathrm{mg} / \mathrm{dl}$, ALP $81 \mathrm{U} / \mathrm{L}$, AST $10 \mathrm{U} / \mathrm{L}$, ALT $8 \mathrm{U} / \mathrm{L}$, protein $7 \mathrm{~g} / \mathrm{dl}$, albumin $3.6 \mathrm{~g} / \mathrm{dl}$, sedimentation rate $57 \mathrm{~mm} / \mathrm{h}$, anti ds-DNA (-), ANA (-), P-ANCA (-) and C-ANCA (+). C3 $(103 \mathrm{mg} / \mathrm{dl})$ and C4 (15.6 mg/dl) levels were within normal range.

Thyroid function tests [Thyroid-stimulating hormone (TSH) $<0.004 \mathrm{IU} / \mathrm{ml}(0.4-4.0 \mathrm{IU} / \mathrm{ml})$, free triiodothyronine (fT3) $9.85 \mathrm{pg} / \mathrm{ml}(1.57-5.10 \mathrm{pg} / \mathrm{ml})$, free thyroxine (fT4) $>6 \mathrm{ng} / \mathrm{dl}(0.80-1.48 \mathrm{ng} / \mathrm{dl})$ ] were compatible with primary hyperthyroidism. Antithyrotropin receptor anti-bodies (TRAb) and antiperoxidase (anti-TPO) were found $>8.8 \mathrm{U} / \mathrm{L}$ (0-1.75 $\mathrm{U} / \mathrm{L})$ and $>1000 \mathrm{IU} / \mathrm{ml}(0-35 \mathrm{IU} / \mathrm{ml})$, respectively. Urinalysis revealed $\mathrm{pH}$ 5.5, specific gravity 1012, erythrocyte (-), eosinophil (-), protein (+2).

Proteinuria was found as $34.6 \mathrm{mg} / \mathrm{m}^{2} / \mathrm{h}$ and glomerular filtration rate (GFR) as $41 \mathrm{ml} / \mathrm{dk} / 1.73 \mathrm{~m}^{2}$. Based on these findings the patient was diagnosed with stage 3 chronic renal failure.

On thyroid ultrasonography (US) parenchyma was homogen-hypoechoic and had pseudonodular pattern. Increased blood flow on doppler US and thyroid scintigraphy were compatible with Graves's disease.

Renal US showed bilateral renomegaly and grade 2 kidneys compatible with parenchymal renal disease.

Percutaneous renal biopsy showed that fibrinogen, C1q, $\lg \mathrm{A}$ and $\lg \mathrm{M}$ were negative, $\lg \mathrm{G}(+/++)$ and $\mathrm{C} 3(++++)$ mixed granular staining was seen in immunofluorescence assessment. With histopathological examination 48 glomeruli were studied, of which 36 were global sclerotic, however, varying degrees of sclerosis and mesenchymal matrices were observed in 12 glomeruli. The intense chronic inflammation, proximal tubule dilatations, tubular atrophy and interstitial fibrosis were observed in tubulointerstitial area. The histologic examination was compatible with chronic glomerulonephritis (Figure 1). Renal biopsy revealed that pauci-immune glomerulonephritis was PTU-induced.

Adiagnosis of ANCA-associated chronic glomerulonephritis was made and the propylthiouracil therapy was discontinued. She was given pulse methyl prednisolone $\left(30 \mathrm{mg} / \mathrm{m}^{2} / \mathrm{d}\right.$ for 3 days) followed by oral prednisone $(2 \mathrm{mg} / \mathrm{kg} / \mathrm{d})$. She was also treated with enalapril $(0.1 \mathrm{mg} / \mathrm{kg} / \mathrm{day})$, propranolol $(80 \mathrm{mg} /$
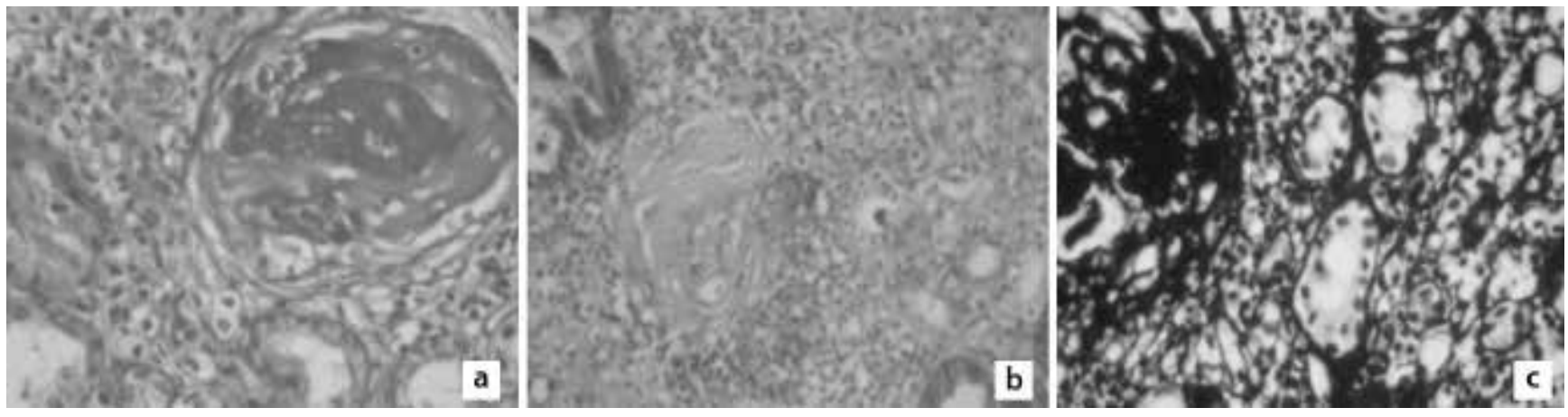

Figure 1. Light microscopy of renal biopsy specimen revealed chronic glomerulonephritis (a. Periodic acid schiff (PAS) stain, b. Trichrome stain, c. Methenamine silver stain) 
day) for hypertension, proteinuria and erythropoietin (EPO) for persistent anemia. Radioactive iodine ablation therapy was performed because of persistent hyperthyroidism. After radioactive iodine therapy, fT3, fT4 regressed from $9.85 \mathrm{pg} /$ $\mathrm{mL}$ to $3.38 \mathrm{pg} / \mathrm{mL}$ and from $>6 \mathrm{ng} / \mathrm{dl}$ to $2.18 \mathrm{ng} / \mathrm{dl}$ within one month. In the sixteenth month of follow-up, her proteinuria, C-ANCA and serum creatinine value regressed to $26 \mathrm{mg} /$ $\mathrm{m}^{2} / \mathrm{h}, 1 / 20$ and $1.3 \mathrm{mg} / \mathrm{dl}$, respectively. GFR was calculated as $47 \mathrm{ml} / \mathrm{dk} . / 1.73 \mathrm{~m}^{2}$. Currently, she is in follow-up with enalapril therapy.

\section{Discussion}

This case highlights that ANCA-positive glomerulonephritis should be considered as a potential side-effect of PTU. Our case report suggests that patients treated with PTU should be carefully monitored for ANCA titers and the variable manifestations of ANCA-associated glomerulonephritis regardless of the period of administration.

The side effects of PTU treatment are generally agranulocytosis, dermatitis, urticaria, arthralgia, arthritis, lupus-like syndrome, lymphadenopathy, nausea, edema and conjunctivitis $(10,11)$. Other rare but serious side effects include drug-induced hepatitis, vasculitis and ANCA related glomerulonephritis (12).

A high prevalence of ANCA positivity in PTU treated patients with childhood onset Graves' disease has been reported (13). The mechanisms of ANCA production and vasculitis in PTU therapy remain unclear. Kitahara et al. (14) proposed that during PTU therapy if neutrophils are activated by infection, a large quantity of ANCA is released from neutrophils, transforming the drug into free radicals, resulting in endothelial injury. In previous studies, P-ANCA was more frequently observed in patients with PTU-induced smallvessel vasculitis. Compared with primary ANCA-induced small-vessel vasculitis, the patient with PTU-induced smallvessel vasculitis had higher positive rate of P-ANCA $(5,15)$. In contrast, only C-ANCA was detected positive in our case.

It has been suggested that most patients present with systemic symptoms including fever, fatigue, arthritis, scleritis and rash. Furthermore nephritis, with or without systemic involvement, is present in about two thirds of the patients (8). Although our subject did not have symptoms such as fever, malaise, arthritis, scleritis and skin eruption during referral; elevated serum urea and creatinine, proteinuria and decreased GFR were present. Renal biopsy findings were consistent with glomerulonephritis.

Treatment for ANCA positive glomerulonephritis should be given appropriately depending on the severity of the illness. Corticosteroids and/or cyclophosphamide are warranted if renal manifestations are severe or rapidly progressive or if biopsy findings show crescentic glomerulonephritis (8). In the previous study, compared with primary ANCA-associated small vessel vasculitis, patients with PTU-induced smallvessel vasculitis have milder renal impairment and better prognosis (5). Chen et al. investigated the clinical outcomes of patients with PTU- associated ANCA vasculitis treated with steroids and received immnosuppressive therapy and it was seen that most of the patients had complete renal remission. On the other hand, $25 \%$ of the patients developed ESRD. We treated our patient with corticosteroid therapy alone. In the sixteenth month of follow-up, partial remission and stage 3 chronic renal failure were observed (4).

In conclusion, physicians should have a high index of suspicion in patients receiving PTU with symptoms or signs suggestive of renal disease in terms of ANCA positive glomerulonephritis without other common side effects. Especially, patients treated with PTU should be carefully monitored for ANCA titers and the variable manifestations of ANCA-associated glomerulunephritis regardless of the period of administration. Furthermore, when ANCA positive glomerulonephritis develops during PTU therapy; an alternative agent, such as methimazole, thyroidectomy and RAl ablation therapy are options for treating underlying hyperthyroidism $(16,17)$.

Conflicts of Interest: The authors reported no conflict of interest related to this article.

\section{References}

1. Noh JY, Yasuda S, Sato S, et al. Clinical characteristics of myeloperoxidase antineutrophil cytoplasmic antibodyassociated vasculitis caused by antithyroid drugs. J Clin Endocrinol Metab 2009; 94:2806-11.

2. Vogt BA, Kim Y, Jennette JC, Falk RJ, Burke BA, Sinaiko A. Antineutrophil cytoplasmic autoantibody-positive crescentic glomerulonephritis as a complication of treatment with propylthiouracil in children. J Pediatr 1994; 124:986-8.

3. Wing SS, Fantus IG. Adverse immunologic effects of antithyroid drugs. CMAJ 1987; 136:121-7.

4. Chen $Y$, Bao H, Liu Z, Zhang H, Zeng C, Liu Z, Hu W. Clinico-pathological features and outcomes of patients with propylthiouracil-associated ANCA vasculitis with renal involvement. J Nephrol 2014; 27:159-64.

5. Cao X, Lin W. Clinical study of renal impairment in patients with propylthiouracil-induced small-vessel vasculitis and patients with primary ANCA-associated small-vessel vasculitis. Exp Ther Med 2013; 5:1619-22.

6. Prasad GVR, Bastacky S, Johnson JP. Propylthiouracilinduced diffuse proliferative lupus nephritis: review of immunological complications. J Am Soc Nephrol 1997; 8:1205-10.

7. Pillinger M, Staud R. Wegener's granulomatosis in a patient receiving propylthiouracil for Grave's disease. Semin Arthritis Rheum 1998; 28:124-9.

8. Gunton JE, Stiel J, Caterson RJ, Mc Elduff A. Anti-thyroid drugs and antineutrophil cytoplasmic antibody positive vasculitis. A case report and review of the literature. J Clin Endocrinol Metab 1998; 84:13-6.

9. Reinhart SC, Moses AM, Cleary L, Scheinman SJ. Acute interstitial nephritis with renal failure associated with propylthiouracil therapy. Am J Kidney Dis 1994; 24:575-7.

10. Cooper DS. Antithyroid drugs. N Engl J Med 1984; 311:1353-62.

11. Wing SS, Fantus IG. Adverse immunologic effects of antithyroid drugs. CMAJ 1987; 136:121-7.

12. Nakahama $H$, Nakamura $H$, Kitada $O$, Sugita M. Chronic drug-induced tubulointerstitial nephritis with renal failure associated with propylthiouracil therapy. Nephrol Dial Transplant 1999; 14:1263-5. 
13. Dolman KM, Gans RO, Vervaat TJ, Zevenbergen G, Maingay D, Nikkels RE, et al. Vasculitis and antineutrophil cytoplasmic autoantibodies associated with propylthiouracil therapy. Lancet 1993; 342:651-2.

14. Kitahara T, Hiromura K, Maezawa A, Ono K, Narabara N, Yano S, et al. Case of propylthiouracil-induced vasculitis associated with anti-neutrophil cytoplasmic antibody (ANCA); review of literature. Clin Nephrol 1997; 47:33640.
15. Rutgers A, Kallenberg CG. Refractory disease in antineutrophil cytoplasmic antibodies associated vasculitis. Curr Opin Rheumatol 2012; 24:245-51.

16. Goichot B, Vinzio S. Antithyroid drugs. N Engl J Med 2005; 352:2246-7.

17. Rivkees SA, Sklar C, Freemark M. Clinical review 99: The management of Graves' disease in children, with special emphasis on radioiodine treatment. J Clin Endocrinol Metab 1998; 83:3767-76. 